\title{
Baseline study of methane emission from anaerobic ponds of palm oil mill effluent treatment
}

\begin{abstract}
The world currently obtains its energy from the fossil fuels such as oil, natural gas and coal. However, the international crisis in the Middle East, rapid depletion of fossil fuel reserves as well as climate change have driven the world towards renewable energy sources which are abundant, untapped and environmentally friendly. Malaysia has abundant biomass resources generated from the agricultural industry particularly the large commodity, palm oil. This paper will focus on palm oil mill effluent (POME) as the source of renewable energy from the generation of methane and establish the current methane emission from the anaerobic treatment facility. The emission was measured from two anaerobic ponds in Felda Serting Palm Oil Mill for 52 weeks. The results showed that the methane content was between $35.0 \%$ and $70.0 \%$ and biogas flow rate ranged between 0.5 and $2.4 \mathrm{~L} / \mathrm{min} / \mathrm{m} 2$. Total methane emission per anaerobic pond was $1043.1 \mathrm{~kg} /$ day. The total methane emission calculated from the two equations derived from relationships between methane emission and total carbon removal and POME discharged were comparable with field measurement. This study also revealed that anaerobic pond system is more efficient than open digesting tank system for POME treatment. Two main factors affecting the methane emission were mill activities and oil palm seasonal cropping.
\end{abstract}

Keyword: Greenhouse gases (GHG); Methane; Palm oil mill effluent (POME); Anaerobic ponds/lagoons. 